\title{
PERENCANAAN KOMUNIKASI PROGRAM OJEK MAKANAN BALITA (OMABA) DALAM MEMBENTUK PERSEPSI ORANG TUA MENGENAI ANAK GIZI BURUK \\ (STUDI DESKRIPTIF PADA ORANG TUA DENGAN RIWAYAT ANAK GIZI BURUK DI KELURAHAN CISARANTEN KIDUL, GEDE BAGE)
}

\author{
Nancy Citra Purnaningtyas ${ }^{1}$ ), Nofha Rina ${ }^{2}$ ) \\ 1) Program Studi Ilmu Komunikasi Universitas Telkom \\ ${ }^{2)}$ Program Studi Ilmu Komunikasi Universitas Telkom \\ Email ;1) nancyningtyas@gmail.com, ${ }^{2}$ )nofharina80@gmail.com
}

\begin{abstract}
Nowadays malnutrition is one of big problem that still being a government concern in health sector. At Gede Bage Bandung City on 2013 there are 29 cases of malnutrtion founded, 17 cases of them is at Cisaranten Kidul which is under the responsibility of Riung Bandung Public Health Center. Riung Bandung Public Health Center has succeeded in doing an innovation of health program called Ojek Makanan Balita (OMABA) which able to reduce malnutrition rate. The purpose of this research is to know the communication planning of OMABA program in shaping the perception of parents with children who have history of malnutrition in Cisaranten Kidul. The method used in this research is descriptive qualitative method by using in-depth interview technique which also supported with documentation obtained from Riung Bandung Public Health Center. The result of this research is that communication planning in OMABA program has been implemented systematically and structured and this program is able to form a perception to the participants that eat healthy food and that healthy food does not have to be expensive.
\end{abstract}

Keywords: Communication Planning, Malnutrition, Perception

\section{PENDAHULUAN}

Balita merupakan kelompok usia yang paling rentan terhadap berbagai kasus yang berkaitan dengan kesehatan, salah satunya adalah rentannya mengalami kondisi gizi buruk. Terlebih balita pada rentang usia 0-2 tahun merupakan masa emas (golden period) bagi pertumbuhan dan perkembangan balita itu sendiri. Akibat yang dapat ditimbulkan dari balita yang terkena kasus gizi buruk adalah, balita-balita tersebut menjadi lebih rentan terhadap penyakit dan berbagai infeksi, bahkan dapat menyebabkan kematian pada anak.

Gizi buruk kerapkali terjadi pada balita dengan kondisi keluarga ekonomi-sosial menengah kebawah, namun bukan berarti gizi buruk hanya terjadi di daerah-daerah yang dianggap tertinggal. Seperti yang diketahui, Jawa Barat merupakan provinsi dengan penduduk terbanyak yaitu sejumlah 45.472.830 jiwa dan merupakan provinsi yang memiliki keadaan ekonomi yang cukup baik, namun berdasarkan data yang diperoleh dari 
Ditjen Kesehatan Masyarakat, Kemenkes RI pada tahun 2013 angka gizi buruk di Jawa Barat pun dapat dikategorikan cukup tinggi, karena Jawa Barat menempati urutan ketiga Kasus Gizi Buruk ditemukan.

\section{Gambar 1.}

\section{Data Kasus Gizi Buruk di Indonesia} Tahun 2013

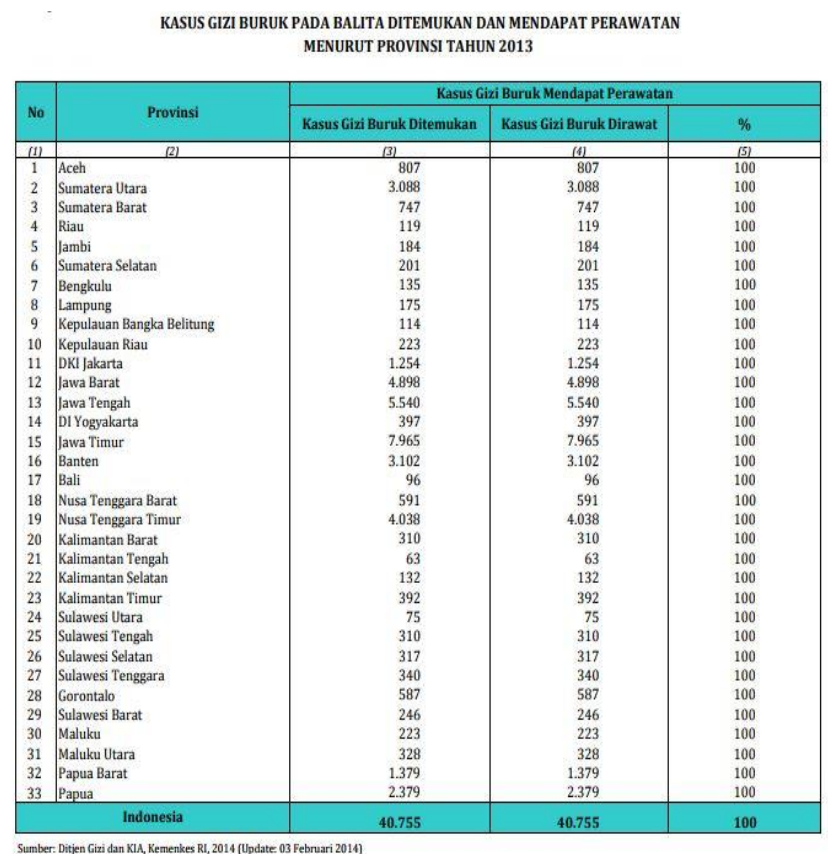

Sumber: Profil Kesehatan Indonesia 2013, Kementerian Kesehatan RI

Gizi buruk di Jawa Barat tidak hanya terjadi di kota dan kabupaten kecil saja, bahkan di Ibu Kota Provinsi Jawa Barat pun yakni Kota Bandung hingga tahun 2012 masih terdapat 289 kasus balita gizi buruk yang ditemukan di Kota Bandung. salah satunya di Kelurahan Cisaranten Kidul, Gede Bage, yangmerupakan salah satu daerah ditemukannya cukup banyak angka gizi buruk, pada tahun 2013 ditemukan 29 kasus gisi buruk pada Kecamatan Gede Bage dimana 17 kasus diantaranya adalah warga yang berdomisili di Kelurahan Cisaranten Kidul (Arsip Omaba, 2015) Besarnya angka gizi buruk di Kelurahan Cisaranten Kidul, Gede Bage ini menjadi fokus perhatian dan penanganan UPT Puskesmas Riung Bandung.

\section{Kepala UPT Puskesmas Riung}

Bandung pun memutuskan untuk membuat sebuah inovasi sebagai upaya untuk mengurangi angka gizi buruk di Kelurahan Cisaranten Kidul, Gede Bage, Kota Bandung yang bernama Ojek Makanan Balita (OMABA). Program OMABA ini pertama kali dilaksanakan pada tahun 2013, dimana usulan program ini muncul setelah adanya kematian ibu melahirkan dan juga kematian bayi. Kepala UPT Puskesmas Riung Bandung menginisiasi untuk membentuk program yang dapat mengakomodir kebutuhan gizi bagi anak penderita gizi buruk.

Bantuan dan dukungan yang diberikan oleh ibu-ibu di wilayah Kelurahan Cisaranten Kidul, Gede Bage yang bersedia sebagai sukarelawan, ditemukanlah cara yang menurut Kepala UPT Puskesmas Riung Bandung yakni dengan melakukan Pemberian Makanan Tambahan (PMT)-Pemulihan secara gratis selama 90 hari berturut-turut kepada balita dengan gizi buruk dengan menggunakan cara delivery. Cara tersebut dipilih karena dirasa tepat untuk menjadi solusi atas permasalahan yang ada yakni berpencar-pencarnya domisili 
balita yang terkena gizi buruk (Arsip OMABA, 2015).

Pelaksana kegiatan ini merupakan ibuibu yang menjadi sukarelawan dan berada di lingkungan Kelurahan Cisaranten Kidul, Gede Bage yang menjadi terkenal dengan istilah "Ibu-ibu OMABA". Ibu-ibu OMABA ini tidak hanya mendistribusikan begitu saja PMTPemulihan yang telah disiapkan, tetapi juga memberi edukasi tentang pentingnya makanan bergizi bagi balita kepada orang tua dan juga memastikan bahwa PMT-Pemulihan tersebut memang dihabiskan oleh balita gizi buruk yang dimaksud. Berdasarkan informasi yang diperoleh, program inovasi OMABA ini telah memberikan berbagai output yang menunjukkan bahwa OMABA ini merupakan progam efektif. Hal yang menunjukkan keberhasilan program OMABA adalah menurunnya gizi buruk dari 29 kasus pada tahun 2013 menjadi hanya 4 kasus gizi buruk pada tahun 2015 (Arsip OMABA, 2015). Kondisi-kondisi diatas dapat terjadi pasca dilakukannya pemberian PMT-Pemulihan yang intensif selama 90 hari berturut-turut.

Keberhasilan dalam mengurangi angka gizi buruk di Kelurahan Cisaranten Kidul, Gede Bage tidak terlepas dari perencanaan komunikasi. Menurut AMIC perencanaan komunikasi merupakan suatu usaha yang sistematis dan kontinu dalam mengorganisasi aktivitas manusia terhadap upaya penggunaan sumber daya komunikasi secara efisien guna merealisasikan kebijakan komunikasi (Cangara, 2014: 48).

Perencanaan Komunikasi adalah salah satu cara yang dilakukan sebagai pendekatan kepada orang tua dengan anak yang bergizi buruk, sehingga orang tua tersebut dapat menyadari bahwa kecukupan gizi untuk anak adalah hal yang penting untuk diperhatikan. Salah satu model perencanaan komunikasi yang dapat dilakukan dalam melaksanakan program Ojek Makanan Balita (OMABA) ini adalah model alur "P" proses. Model perencanaan komunikasi "P" Proses ini merupakan model yang sudah banyak digunakan dalam banyak program promosi kesehatan yang sudah dilaksanakan sejak tahun 1982 dimana model ini dikembangkan oleh John Hopkins Bloomberg School of Public Relation. Tujuan dari adanya model perencanaan komunikasi "P" proses ini adalah untuk menganalisis realitas kondisi kesehatan masyarakat, mendesain komunikasi yang akan disampaikan, mengembangkan media, implementasi, monitoring, dan assessment isi pesan, dan menelaah hasil dari strategi komunikasi. (Notoatmodjo, 2012)

Selain keingintahuan penulis terkait dengan perencanaan komunikasi yang dilakukan oleh UPT Puskesmas Riung Bandung, Kelurahan Cisaranten Kidul, Gede Bage, Kota Bandung dalam upaya mengurangi angka gizi buruk, penulis pun ingin mencari tahu persepsi apa yang berhasil dibentuk oleh 
pihak pelaksana program Ojek Makanan Balita (OMABA) kepada orang tua yang memiliki anak dengan riwayat gizi buruk. Seperti yang disamapaikan oleh Sereno dan Bodaken dalam Mulyana bahwasanya persepsi merupakan salah satu wadah dalam pikiran kita yang memungkinkan kita memperoleh kesadaran di dalam lingkungan kita. Persepsi sendiri meliputi penginderaan (sensasi) melalui alatalat indera kita (indera peraba, indera penglihat, indera pencium, indera pengecap, dan indera pendengar), perhatian, serta interpretasi. Dalam penelitian ini penulis akan menganalisis persepsi dengan menggunakan faktor-faktor pembentukan persepsi yang disampaikan oleh Krech dan Crutchfield (1977) (dalam Rakhmat, 2012: 51-57) yakni faktor perhatian, Faktor Fungsional, dan Faktor Struktural.

Berdasarkan penjabaran dan data-data yang sudah penulis uraikan diatas, maka penulis merasa tertarik untuk melakukan penelitian dengan judul "Perencanaan Komunikasi Program Ojek Makanan Balita (OMABA) dalam Membentuk Persepsi Orang Tua Mengenai Anak Gizi Buruk (Studi Deskriptif pada Orang Tua dengan Riwayat Anak Gizi Buruk di Kelurahan Cisaranten Kidul, Gede Bage, Kota Bandung)", dimana penelitian ini bertujuan untuk mengetahui bagaimana perencanaan komunikasi dari program Ojek Makanan Balita (OMABA) dalam membentuk persepsi orang tua yang memiliki anak dengan riwayat gizi buruk.

\section{METODOLOGI PENELITIAN}

Pada penelitian ini, penulis akan menggunakan metode penelitian deskriptif kualitatif. Dimana Jane Richie mendefinisikan bahwa penelitian kualitatif adalah suatu upaya untuk menjelaskan tentang dunia sosial dan perspektifnya di dalam dunia, baik itu dari segi konsep, tingkah laku, persepsi, dan berbagai hal yang berkaitan dengan manusia yang diteliti. (Moleong, 2014: 6). Maka, dpaat disimpulkan bahwa penelitian ini mencoba untuk mendeskripsikan sebuah fenomena yang diperoleh dengan melihat berbagai perilaku dan memahami persepsi manusia yang diteliti.

Subjek dari penelitian ini adalah UPT Puskesmas Riung Bandung yang merupakan pelaksana dari program Ojek Makanan Balita (OMABA) ini. Sedangkan objek dari penelitian ini adalah Perencanaan Komunikasi yang dilaksanakan dalam menjalani program Ojek Makanan Balita (OMABA) dalam membentuk persepsi orang tua dengan riwayat anak bergizi buruk di Kelurahan Cisaranten Kidul, Gede Bage, Kota Bandung agar lebih peduli terhadap kecukupan gizi anak mereka.

Pada penelitian ini, penulis melakukan pengumpulan data primer dengan teknik wawancara mendalam (in-depth interview). Wawancara akan dilakukan kepada pihak pelaksana dan penanggungjawab program 
OMABA, yaitu dr. Sonny Sondari, M.Kes yang merupakan kepala UPT Puskesmas Riung Bandung sekaligus inisiator program OMABA, kemudian Ibu Nok Aas Sukaesih yang merupakan pelaksanan lapangan dalam program OMABA, lalu Ibu Vita Fatimah selaku Ketua Komite Kesehatan Kelurahan Cisaranten Kidul. Dimana dilakukan wawacara dengan ketiga informan tersebut untuk mengetahui bagaimana perencanaan komunikasi yang dilakukan. Penulis juga melakukan mewawancarai 3 (Tiga) orang tua yang memiliki anak riwayat gizi buruk dan pernah menjadi peserta OMABA untuk mengetahui persepsi apa yang terbentuk setelah menjadi peserta OMABA, ketiga orang tersebut adalah Ibu Yuli, Ibu Lilis, dan Ibu Juariah. Penulis pun melakukan wawancara dengan satu informan ahli yakni Ibu Yani Heryani yang merupakan staff Dinas Kesehatan Bandung Barat. Untuk melengkapi data primer tersebut, penulis melakukan studi literatur pada penelitian terdahulu yang berkaitan, melakukan kajian pada sumbersumber buku yang berhubungan, menggunakan sumber internet, dan menggunakan dokumentasi yang diperoleh dari UPT Puskesmas Riung Bandung. Dari data-data tersebut penulis memperoleh data bayi yang menderita gizi buruk di Kelurahan Cisaranten Kidul Gede Bage pada tahun 2015 sebagai berikut;

\section{Gambar 2. Data Balita Gizi Buruk Peserta OMABA}

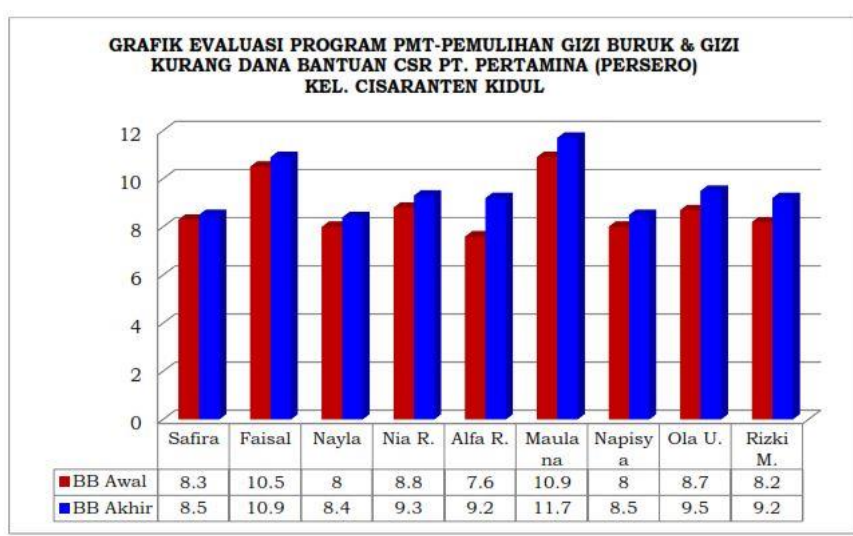

Sumber: Arsip OMABA, 2015

Agar dapat menentukan keabsahan atau truthworthiness didalam data, dibutuhkan teknik pemeriksaan. Penulis menguji keabsahan data penelitian ini dengan melakukan triangulasi, Teknik triangulasi yang umumnya digunakan adalah melakukan pemeriksaan melalui sumber yang lainnya (Moleong, 2014: 330). Penulis akan menggunakan triangulasi sumber sebagai teknik keabsahan data, dimana penulis nantinya akan membandingkan dan memeriksa kembali kebenaran suatu informasi yang diperoleh dengan waktu dan instrumen yang berbeda.

Pada penelitian ini penulis akan menggunakan teknik analisis data yang dikemukakan oleh Miles dan Huberman (1984) (dalam Sugiyono, 2011; 244). Miles dan Huberman mengatakan bahwa analisis data kualitatif dilakukan dengan cara yang interaktif. Terdapat tiga aktifitas dalam analisis data menurut Miles dan Huberman yaitu; (1) Reduksi Data, Reduksi data adalah 
merangkum, memilih dan memfokuskan pada hal-hal yang penting, menentukan tema serta pola dari data yang ada. Data yang telah direduksi akan menghasilkan suatu gambaran hasil dan membantu peneliti untuk mengambil data selanjutnya jika diperlukan. (2) Penyajian Data, Langkah ini dapat dilakukan dalam bentuk uraian singkat, bagan-bagan, flowchart, dan sebagainya. Menurut Miles dan Huberman yang paling sering digunakan untuk penyajian data dalam penelitian kualitatif biasanya dalam bentuk teks atau narasi. (3) Penarikan Kesimpulan dan Verifikasi, Kesimpulan awal yang dikemukakan masih bersifat sementara yang masih dapat terjadi perubahan jika pada pengumpulan data berikutnya peneliti memperolah data-data yang lebih menguatkan. Namun jika kesimpulan sudah didukung oleh bukti-bukti yang valid dan konsisten saat peneliti kembali ke lapangan untuk mengumpulkan data, maka kesimpulan yang dikemukakan dianggap kredibel.

Penelitian ini akan mengamati program Ojek Makanan Balita (OMABA) dengan menggali informasi dari pihak pelaksana program OMABA (UPT Puskesmas Riung Bandung dan Ibu-ibu OMABA) serta menggali informasi dari orang tua yang memiliki anak dengan riwayat gizi buruk yang pernah menjadi peserta OMABA. Penelitian ini dilakukan sejak September 2017 hingga Januari 2018.

\section{HASIL DAN PEMBAHASAN}

Berdasarkan dengan hasil penelitian yang sudah dikumpulkan oleh penulis, tahapan pertama yang dilakukan yakni analisis epideimologi, di daerah Kelurahan Cisaranten Kidul ditemukan kasus gizi buruk yang berhasil teridentifikasi oleh pihak UPT Puskesmas Riung Bandung. Gejala ketika balita terkena gizi buruk tergambarkan dari pernyataan yang disampaikan oleh Dokter Sonny selaku informan kunci dan Ibu Yani selaku informan ahli, yakni sebagai berikut

“...jadi kita itu punya standar pengukuran, yang kita biasanya lihat di KMS (Kartu Menuju Sehat), biasanya kalo anak 3 bulan dia tidak naik-naik, kalo (di bawah garis) merah jauh udah pasti gizi buruk. Tapi dari kuning yang dibawah mendekati merah, itu kita sudah harus hati-hati (...). Jadi ada tolak ukur yang biasanya dikerjakan oleh kader posyandu dan petugas gizi puskesmas juga." (Hasil wawancara dr. Sonny, 15 Desember 2017)

"biasanya dari fisiknya juga kelihatan sih, dari mukanya, biasanya mukanya lebih pucat gitu ya, matanya juga beda gitu. terus, badannya biasanya kecil kurus. Biasanya sih kalo paling kelihatan tuh di bagian pantatnya. Pantatnya tuh biasanya kita bilangnya baggy pants, jadi kaya melorot gitu jadi tinggal kulit aja, tapi biasanya kalo itu sih udah parah banget. terus rambutnya juga kuning-kuning" (Hasil Wawancara Ibu Yani, 6 Januari 2018)

Jika kita meninjau kembali makna dari analisis epideimologi yang memiliki makna analisis yang mencakup kelaziman penyakit, karakteristik penderita, faktor-faktor resiko yang timbul, serta penyebab utama dari 
penyakit (Notoatmodjo, 2012), maka UPT Puskesmas Riung Bandung terlihat sudah melakukan proses analisis epideimologi sebelum menjalankan atau melanjutkan sebuah program kesehatan.

Selain melakukan analisis epideimologi penting juga untuk melakukan analisis perilaku agar tahapan analisis atau riset ini dapat dijalani dengan maksimal. Berdasarkan hasil penelitian, perilaku masyarakat Kelurahan Cisaranten Kidul terutama keluarga yang dimana didalamnya terdapat balita bergizi buruk, biasanya kondisi perekonomiannya ada di taraf ekonomi rendah, sehingga orang tua nya tidak begitu memperhatikan kebutuhan gizi bagi anaknya ketika memberikan makanan. Selain itu, di Kelurahan Cisranten Kidul itu masih terdapat kantung-kantung kemiskinan, dimana kantungkantung kemiskinan ini erat kaitannya dengan keluarga miskin dan lingkungan hidup yang tidak bersih dan tidak sehat, di Kelurahan Cisaranten Kidul ini masih terdapat rumahrumah tidak layak huni dan sanitasi yang masih buruk, selain itu kantung kemiskinan pun erat kaitannya dengan keterbatasan pengetahuan. Seperti kutipan yang disampaikan oleh informan berikut ini,

"disana (Kelurahan Cisaranten Kidul) ada kantung2 kemiskinan sehingga dari situ masalah mulai muncul, kantung kemiskinan itu kan identik dengan penyakit, kekurangan gizi, sanitasi yang jelek, rumah yang tidak layak huni, seperti itu. nah, kemudian disitulah masalahnya muncul, gitu ya (...). Yang jelas mah itu miskin, ketiadaan sumber daya, gak bisa ada yang diolah, dia makan ya seadaadanya makanan kan, dia pikir mie instan itu berupa makanan gitu. Kemudian, pengetahuannya, ya kita tahu ya kemiskinan, kebodohan, pengetahuan rendah, itu biasanya satu paket. Nah untuk edukasi juga memang kita harus hati-hati dan sangat terus-menerut tidak bisa sekali, makanya 3 bulan itu merupakan suatu edukasi yang lumayan mengena ya" (Hasil wawancara dr. Sonny, 15 Desember 2017).

Dapat dilihat bahwa UPT Puskesmas Riung Bandung telah melaksanakan analisis perilaku dengan hampir sempurna, karena sejauh ini fokus dari UPT Puskesmas Riung Bandung adalah masih mengupayakan pengobatan kepada penderita gizi buruk, namun belum melakukan tindak pencegahan gizi buruk yang sangat berpengaruh secara signifikan.

Tahapan kedua yang dilakukan adalah menyusun desain komunikasi, dimana dalam tahapan ini terdapat beberapa langkah. Yang pertama adalah menentukan khalayak sasaran, berdasarkan hasil penelitian, didapatkan fakta bahwa khalayak sasaran dari program ini adalah balita yang dimana kondisi kecukupan gizi nya masih belum dapat terpenuhi atau biasa diketahui sebagai balita dengan gizi buruk. Khalayak sasaran yang merupakan balita bergizi buruk ini merupakan alasan utama mengapa hingga akhirnya program ini pun disusun. Berikut adalah balita gizi buruk yang merupakan peserta program OMABA; 


\section{Gambar 3. Khalayak Sasaran Program OMABA}
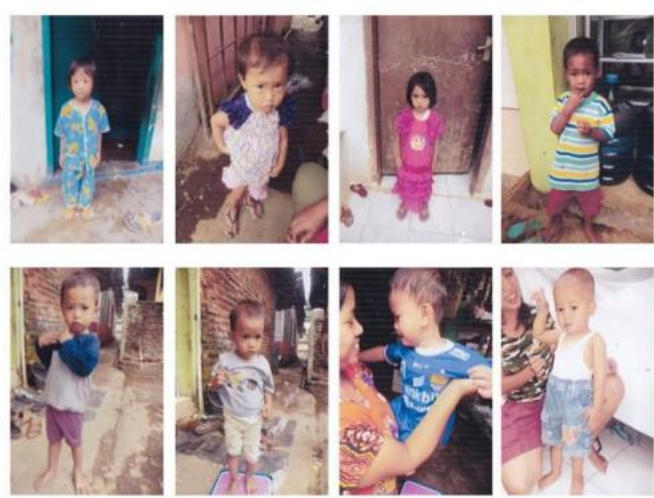

Sumber: Arsip OMABA, 2015

Kemudian dalam tahapan menyusun desain komunikasi, penting hal nya untuk menentukan tujuan dari suatu program, dimana tujuan utama dari program OMABA ini adalah untuk memecahkan permasalahan gizi buruk di Kelurahan Cisaranten Kidul serta salah satu tujuan khususnya adalah mengembangkan sistem tata kelola gizi dan distribusi PMT. Dilihat dari penjabaran sebelumnya, dapat diketahui bahwa program OMABA telah menyusun tujuan spesifik sebelum program berjalan.

Hal lainnya yang juga merupakan kunci utama dalam keberlangsungan program ini adalah menentukan isi pesan yang akan disampaikan kepada target sasaran serta menentukan media yang dirasa efektif dalam menyampaikan pesan yang ingin disampaikan. Isi pesan yang ingin disampaikan dari progam OMABA ini pun disampaikan oleh Dokter Sonny selaku Informan Kunci sebagai berikut,

“(...) yaitu makanlah makanan yang baik dan sehat, itu. Kan sekarang ini sudah banyak didalam kepala orang, bahwa yang kita makan ini yaudah makanan tuh apa aja yang bisa dimakan, yang penting kenyang. Terus, kan toh dijual dipasaran, yang berarti sudah diizinkan, nah itu yang menjadi musuh kita. Lalu masyarakat kan bisa dengan bebas mengkonsumsi, padahal tidak seperti itu kenyataannya, jadi makanan yang dimakan, yang kita makan tuh belum tentu sehat. Jadi, misi kita adalah memperlihatkan dan mengedukasikan makanan sehat tuh kaya gini, mbok ya yang dimakan seperti ini. Ya, jadi itu sih pesan utama-nya, makanlah makanan yang baik dan sehat." (Hasil wawancara dr. Sonny, 15 Desember 2017)

Kemudian untuk media yang dirasa tepat untuk digunakan dalam penyampaian pesan ini, sejauh ini jenis komunikasi yang digunakan hanya menggunakan metode konseling atau komunikasi interpersonal saja, karena cara ini adalah cara yang dianggap paling efektif untuk kalangan ekonomi bawah, karena jika menggunakan media yang lebih kompleks, maka pesan yang akan disampaikan akan lebih sulit untuk dipahami. Namun, sangat disayangkan karena berdasarkan dengan apa yang ditemukan di lapangan, UPT Puskesmas Riung Bandung belum mengemas secara khusus dan spesifik pesan yang ingin disampaikan, semuanya masih terjadi secara spontanitas, tanpa adanya perencanaan khusus tentang cara penyampaian pesan.

Langkah terakhir yang dilakukan pada tahap desain komunikasi ini adalah menyusun strategi pelaksanaan dan rencana tindakan. Langkah ini dilakukan agar nantinya dalam pelaksanaan program dapat berjalan lebih terstruktur dan sistematis. Untuk persiapan 
konsep dan sistematika program, sebelumnya kepala UPT Puskesmas Riung Bandung telah menyiapkan berbagai macam hal seperti dana pembiayaan, selain itu sarana prasarana juga harus turut disiapkan seperti dapur yang akan dijadikan basecamp, kemudian yang paling penting adalah mempersiapkan Sumber Daya Manusia yang memang memiliki kapabilitas untuk turut berpartisipasi dalam program OMABA ini, sehingga dilatihlah para Sumber Daya Manusia tersebut agar memiliki kapabilitas yang cukup dan sesuai kebutuhan. Untuk persiapan strategi pelaksanaan lapangan yang dilakukan setiap harinya selama program berlangsung adalah adanya jadwal piket untuk menentukan ibu-ibu OMABA yang akan bertugas setiap harinya, dimulai dari siapa yang akan menyiapkan PMT, siapa yang akan mengantar makanan dan juga penentuan menu setiap harinya agar makanan OMABA tetap variatif dan dapat menarik perhatian khalayak sasaran yang disusun.

Tahapan selanjutnya dalam melakukan perencanaan komunikasi adalah pengembangan media yang didalamnya juga terdapat beberapa langkah, yakni desain media, uji coba media, dan finalisasi media. Untuk tahapan desain media, berdasarkan temuan lapangan, bahwa hingga saat ini media yang digunakan dalam program OMABA masih belum terformulasikan dengan baik, masih sebatas melakukan pendekatan personal yang dilakukan secara spontan dan penggunaan PMT-Pemulihan tersebut sebagai media yang diupayakan agar terus meningkat kualitasnya dan menambah variasi masakan dari makanan yang diantarkan. Hambatan tersebut terjadi karena sebelumnya UPT Puskesmas Riung Bandung tidak memiliki ahli gizi masyarakat yang juga berfokus kepada kegiatan promosi kesehatan dan juga dikarenakan latar belakang dari khalayak sasaran yang dituju sebagian besar merupakan masyarakat dengan tingkat ekonomi rendah, sehingga perencana harus memikirkan cara apa yang efektif dan ringan sehingga makna yang ingin disampaikan dapat dipahami oleh khalayak tersebut. Sulitnya khalayak sasaran memahami pesan atau makna yang dimaksud jika cara penyampaian tidak efektif dan tidak mudah dipahami adalah karena pada umumnya orang tua pesetra OMABA ini memiliki keterbatasan pendidikan dan pengetahuan, sehingga tugas bagi OMABA adalah dapat menyampaikan makna secara ringan dan mudah dipahami.

Kemudian untuk uji coba media yang dilakukan hanya kepada makanan yang akan diantarkan, uji coba dilakukan dengan memeriksa apakah makanan tersebut memang makanan sehat atau tidak. Sejauh ini OMABA tidak pernah melakukan uji coba program secara khusus, karena program OMABA ini menerapkan sistem learning by doing, sehingga program ini langsung dijalankan dan menganggap semua yang terjadi dalam satu 
periode merupakan bahan evaluasi bagi program OMABA periode selanjutnya. Kemudian, dalam program OMABA hingga saat ini yang masih harus diperbaiki adalah menu makanan agar semakin variatif sehingga program OMABA ini pun tetap terlihat menarik namun tetap mudah untuk ditiru oleh para orang tua peserta OMABA agar kecukupan gizinya dapat terpenuhi.

Tahapan ketiga adalah Implementasi, Monitoring, Assessment. terdapat beberapa hal yang harus dilaksanakan dalam tahapan ini, seperti pemberian pelatihan kepada komunikakator, memerhatikan peluncuran program, monitoring atau pemantauan, melihat dampak yang ditimbulkan, baik itu dampak positif maupun negatif. Untuk langkah pertama yaitu pemberian pelatihan bagi komunikator, seperti hal nya yang disampaikan oleh Ibu Nok yang merupakan komunikator dari program OMABA ini, yakni sebagai berikut;

"pelatihannya untuk Ibu-Ibu Omaba? Yang Ibu inget pelatihannya itu, cara pengolahan makanan sehat, utamanya itu tentunya yang di Poltekkes Gizi, kami semuanya udah dapet sertifikatnya masing-masing umum dan khusus gitu, misalkan Ibu A dapet ini, dapet sertifikat khusus itu, terus juga cara konseling gizinya ada pelatihannya juga, terus cara-cara gimana sih menu seimbang itu kaya gitu kan pengetahuan tentang gizinya sendiri. Terus dulu makanan sehat itu 4 sehat 5 sempurna tambah susu, sekarang nggak lagi seperti itu kan. Sekarang harus itu Buah dan sayur itu harus di nomor satu. Bukan 5 sempurna lagi, Buah dan sayur, sayur dan
Buah, termasuk susu ya kan ini namanya PMT, Pemberian Makanan Tambahan. Itukan kita dapet pelatihan juga." (Hasil wawancara Ibu Nok, 22 Desember 2017)

Peluncuran program sangat penting dilakukan guna memperkenalkan keberadaan program kepada khalayak sasaran. Sejak tahun 2013 sebelum melaksanakan program OMABA, petugas UPT Puskesmas Riung Bandung bekerja sama dengan Posyandu yang berada di daerah Kelurahan Cisaranten Kidul, melakukan pengenalan program kepada khalayak sasaran dengan menghampiri kerumah-rumah dan melakukan validasi untuk memastikan apakah anak tersebut memang butuh bantuan PMT atau tidak sembari memberikan informasi tentang OMABA, namun sesungguhnya launching resmi program ini baru dilakukan pada tahun 2016 dan diluncurkan oleh Walikota Bandung yaitu Bapak Ridwan Kamil.

Saat program sudah terlaksana, penting untuk melakukan pemantauan atau pengawasan suatu program. UPT Puskesmas Riung Bandung telah melakukan pemantauan program melalui petugas kesehatannya, yaitu dengan memeriksa seminggu sekali ke rumah peserta OMABA untuk melihat kemajuan anak setelah mengikuti program OMABA ini. Namun, sesuai dengan hasil wawancara saat melakukan penelitian, program OMABA ini masih berada di titik terendah dalam hal monitoring dan evaluasi. Kemudian, perlu diketahui efek atau pengaruh postif dan negatif 
dari program OMABA. Efek positif dari program OMABA ini diantaranya seperti meningkatnya berat badan anak setelah secara rutin diberikan bantuan PMT-Pemulihan, kemudian berubahnya pemahaman dan perilaku orang tua peserta OMABA, yang sebelumnya tidak memikirkan kesehatan suatu makanan, sering makan makanan instan yang berpengawet dan tidak lagi menggunakan MSG untuk memasak.

Tahapan terakhir dalam perencanaan komunikasi model "P" Proses adalah menelaah atau melakukan review dengan melakukan hasil analisis penilaian, rekomendasi tindak lanjut, dan perencanaan kembali suatu program. Untuk mengetahui bagaimana penilaian atau tolak ukur keberhasilan OMABA, hal ini dilihat dari output yang diperoleh, Berdasarkan hasil temuan di lapangan, saat penulis berdiskusi dengan informan pendukung, program OMABA ini telah berhasil karena telah membuat balita yang memiliki riwayat gizi buruk menjadi sehat dan benar-benar bugar, kemudian orang tua tersebut pun sudah mulai memiliki rasa kepedulian terhadap kesehatan anak, seperti sudah mulai memilih untuk masak dibandingkan membeli yang serba instan, dan sudah mulai mencoba berhenti menggunakan sat MSG ketika sedang memasak.

Langkah selanjutnya adalah rekomendasi tingkat lanjut, langkah ini bermanfaat untuk mempertimbangkan apakah suatu program layak untuk menjadi program yang berkelanjutan atau tidak. Program OMABA sendiri telah berhasil mengurangi angka gizi buruk secara drastis pada tahun 2013. Pada umumnya keluarga yang memiliki anak dengan gizi buruk adalah keluarga yang berada di kelas sosial-ekonomi rendah, sehingga menjadi lebih sensitif dan memiliki pemahaman yang kurang tentang kesehatan karena keterbatasan pengetahuan, maka biasanya keluarga tersebut malu untuk meminta pertolongan kepada orang lain dan lebih memilih untuk membiarkan saja, sehingga dengan cara delivery lah solusinya. Dengan menggunakan metode delivery berarti menunjukkan bahwa UPT Puskesmas Riung Bandung memang peduli terhadap kesehatan warga.

OMABA merupakan program yang layak dijadikan program berkelanjutan, oleh karena itu hal selanjutnya yang harus dipertimbangkan adalah perencanaan kembali program OMABA, dalam melakukan perencanaan kembali, penting untuk memperhatikan manfaat dan kekurangan dari pelaksanaan program sebelumnya, sehingga dapat dijadikan bahan evaluasi bagi pelaksanaan program selanjutnya. Berdasarkan hasil temuan di lapangan program OMABA merupakan program yang membawa manfaat sangat banyak, yaitu berhasil mengurangi angka gizi buruk di Kelurahan Cisaranten 
Kidul, berhasil menunjukkan bahwa program ini merupakan hasil dari kolaborasi banyak elemen seperti pihak puskesmas, kelurahan, perusahaan, hingga masyarakat, program OMABA ini pun membantu dalam membentuk kesadaran suatu keluarga agar lebih peduli kepada kesehatan terutama kecukupan gizi anak. Namun, dibalik manfaat yang ada ini, masih terdapat beberapa kekurangan yang masih harus dibenahi pada program selanjutnya, diantara masih lemahnya cara monitoring dan evaluasi dari program ini, serta pengemasan pesan-pesan yang ingin disampaikan masih belum terformulasikan secara sempurna dan masih belum memiliki strategi khusus dalam penyampaian konten pesan. Selain itu, harapan untuk kedepannya program OMABA ini dapat berkolaborasi dengan elemen lainnya untuk meningkatkan keterampilan orang tua dari anak yang memiliki gizi buruk, sehingga setelah anak tersebut selesai mengikuti OMABA, orang tua nya pun sudah bisa mandiri untuk memenuhi gizi anaknya, tidak lagi bergantung pada OMABA karena sudah memiliki keterampilan yang dapat membantu mencukupi kebutuhan gizi.

Selain perencanaan komunikasi, penulis juga ingin mengetahui persepsi apa yang terbentuk pada orang tua yang anaknya pernah menjadi pesera program OMABA. Hal ini dilihat dari tiga faktor, faktor pertama adalah faktor perhatian untuk mengetahui bagaimana respon orang tua dengan riwayat balita gizi buruk terhadap stimulus yang diberikan oleh pelaksana program OMABA. Awalnya, penulis mencari tahu aapakah terdapat gerakan secara visual yang dilakukan dalam pelaksanaan program, berdasarkan hasil penelitian, terlihat bahwa program OMABA tidak memiliki gerakan secara visual yang memang khusus dilakukan pada saat pelaksanaan program. Namun, mereka sebenarnya melakukan rangsangan visual walaupun hal tersebut bukanlah objek yang bergerak, yaitu dengan menyajikan makanan yang menarik dan unik sehingga dapat melekat dibenak orang tua dengan anak beriwayat gizi buruk. Selain itu, pelaksana lapangan pun menyatakan bahwa gerakan yang biasa dilakukan biasanya hanya melalui gerak tubuh, seperti memberi contoh dan menunjukkan bahwa pelaksana lapangan tersebut menyayangi peserta OMABA layaknya anaknya sendiri dan cara ini pun ternyata cukup melekat dibenak orang tua peserta OMABA karena mereka merasa bahwa ibuibu OMABA ini sangat peduli terhadap kesehatan anak mereka.

Hal lain yang dapat menarik perhatian adalah hal-hal yang mencolok dan yang mudah diingat dari program OMABA ini. Berikut adalah hal yang paling diingat dari program OMABA ini oleh peserta OMABA yang merupakan informan pendukung dalam penelitian ini, 
"hal yang paling saya inget mah ya pemberian makan dong tentunya karena beda gitu makannya, terus pemberian nasehat kesehatan teh harus gimana, ngejelasinnya juga enak neng saya gak pusing dengernya." (Hasil wawancara Ibu Yuli, 4 Januari 2018)

"yang paling diinget apanya ya, paling ya karena $\mathrm{Bu}$ Nok (pendekatannya) bagus, terus adeknya suka disayang-sayang. Suka ngasih tau makanan-makanan sehat teh ya gimana, pokonya kaya yang sayang banget sama si adek teh" (Hasil wawancara Ibu Juariah, 4 Januari 2018)

Kemudian, faktor perhatian yang dapat membentuk persepsi adalah adanya hal-hal baru yang disajikan dalam suatu program. Alasan orang tua peserta OMABA mau mengikuti program OMABA adalah karena merasa tertarik karena program seperti ini belum pernah ada sebelumnya dan mereka sudah tidak tahu bagaimana mengembalikan kondisi kecukupan gizi sang anak, sehingga mereka pun bersedia menjadi peserta program OMABA demi kesehatan anaknya sendiri. Hal lainnya yang unik dan menarik perhatian orang tua peserta OMABA adalah, menu-menu yang disajikan oleh OMABA ini berbeda dan kreatif, sehingga membuat anak peserta OMABA ini menjadi mau makan makanan yang sehat dan ibu nya pun memiliki keinginan untuk mengikuti cara membuat makanan tersebut.

Kemudian, faktor perhatian terakhir adalah bagaimana suatu program dilakukan secara berulang kali dan variatif sehingga mampu menarik perhatian (Rakhmat, 2012).
Pada umumnya manusia lebih mudah untuk mengingat hal yang dilakukan berulang-ulang. Program OMABA sendiri sudah melakukan tindakan perulangan tersebut, yaitu dengan cara terus mengantarkan PMT-Pemulihan kepada peserta OMABA setiap harinya selama 90 hari secara konsisten, sehingga baik peserta OMABA itu sendiri ataupun orang tuanya, selalu teringat dengan program OMABA dan akan memahami tentang makanan sehat karena setiap hari selama 90 hari selalu dipaparkan bagaimana bentuk dari makanan sehat, serta selalu diberikan edukasi secara rutin oleh pelaksana lapangan tentang pentingnya memperhatikan kecukupan gizi sang anak. Seperti hal nya yang disampaikan oleh Ibu Lilis selaku informan pendukung,

"ya rutin kan tiap hari selama tiga bulan (pada saat menjadi peserta OMABA) sampe ada perubahan, terus ada naik berat badannya, dulu mah 7 kilo kecil, sekarang mah udah 16 kilo" (Hasil wawancara Ibu Lilis, 4 Januari 2018)

Faktor persepsi yang kedua adalah faktor fungsional yang berasal dari kebutuhan, pengalaman, latar belakang, dan perilaku hidup. Berdasarkan hasil lapangan, orang tua yang anaknya pernah menajadi peserta OMABA pada umumnya memiliki kesamaan latar belakang dan karakteristik yang sangat berpengaruh dalam pembentukan persepsi, yaitu kondisi ekonomi ketiga yang berada di status tingkat ekonomi rendah, tidak memiliki latar belakang pendidikan yang baik, dan kondisi lingkungan hidupnya berada di daerah 
perkampungan yang kesadaran akan kesehatannya juga masih rendah, hal ini dapat membuat orang tua cukup sulit diberikan pemahaman tentang kesehatan dan kecukupan gizi anak jika komunikatornya tidak dapat menyesuaikan diri dengan latar belakang orang tua-orang tua tersebut. Pelaksana lapangan ini pun telah berhasil memberikan pemahaman kepada orang tua peserta OMABA dengan cara dan pendekatan yang sesuai sehingga orang tua peserta OMABA pun sudah mulai perlahan-lahan mengikuti apa yang dikatakan oleh pelaksana lapangan, seperti contohnya mulai membiasakan diri untuk memasak makanan, tidak memakan makanan instan, kemudian mulai tidak menggunakan zat MSG ketika masak, hal ini dapat terjadi karena peserta OMABA merasa nyaman dan senang ketika pelaksana lapangan sedang memberikan edukasi, sehingga secara alamiah, mereka mengikuti apa yang dianjurkan oleh pelaksana lapangan.

Selain latar belakang dan karateristik orang tua dari peserta OMABA, pola perilaku sehari-hari juga mempengaruhi bagaimana seseorang memahami sesuatu, karena lingkungan pun memiliki andil dalam membentuk cara berpikir seseorang. Ditemukan bahwa orang tua yang anaknya pernah menjadi peserta OMABA sehariharinya masih berkomunikasi, berinteraksi, dan bersosialisasi dengan warga di sekitar tempat mereka tinggal walaupun tidak dilakukan secara intens. Penulis pun pernah melakukan observasi partisipasi dan melihat bagaimana kondisi lingkungan tempat tinggal para peserta OMABA tersebut dan berdasarkan yang penulis lihat saat melakukan observasi, memang kondisi lingkungannya saja bukanlah lingkungan yang sehat dan disekitar rumahnya pun mayoritas merupakan warga dengan ekonomi bawah yang mungkin kurang teredukasi, terlebih berkaitan dengan kesehatan dan kecukupan gizi. Maka, hal ini membuat penulis memahami, mengapa masih ada yang bisa terjangkit gizi buruk.

Tahapan terakhir yang dilakukan dalam pembentukan persepsi ini adalah faktor struktural, dimana kita dapat melihat bagaimana respon pelaksana lapangan terhadap anak gizi buruk dan bagaimana respon orang tua yang anaknya pernah menjadi peserta OMABA terhadap penyelenggaraan program Ojek Makanan Balita (OMABA) ini. Berikut respon yang diberikan oleh pelaksana lapangan program OMABA terhadap peserta OMABA itu sendiri.

"sasaran OMABA yang betul-betul membutuhkan sih yang betul-betul itunya keadaan ekonomi orangtuanya, terus anaknya yang memang memprihatinkan (kondisi gizi nya), memang perlu dibantu sama kita gitu, perkembangan kesehatannya juga, kita lihat pantau di Posyandu itu haduh, naiknya susah, timbangannya, gizinya juga kurang. Nah di situ kita lihatnya, ya umumnya ya yang sasaran OMABA yang kayak gitu keadaannya, yang memprihatinkan gitu, kurang peduli sama kesehatan, bisa dari 
ekonominya, ekonominya lemah" (Hasil wawancara Ibu Nok, 22 Desember 2017)

Lalu, untuk respon yang diberikan oleh orang tua yang anaknya pernah menjadi program OMABA adalah, mereka merasa senang ketika ada pihak yang mau membantu dan peduli akan kesehatan anak mereka, pendekatan yang dilakukan oleh pelaksana lapangan pun dianggap berhasil oleh orang tua peserta OMABA, karena saat program setiap harinya anak yang merupakan peserta OMABA ini selalu menunggu keadiran Ibu Nok (pelaksana program OMABA). Dengan adanya program ini, anak yang merupakan peserta OMABA ini jadi memiliki nafsu makan yang lebih baik dan tidak lagi memilihmilih makanan. Orang tuanya pun menjadi paham dan mengetahui apa-apa saja makanan yang sehat, bagaimana cara mengolah makanan sehat tanpa harus mengeluarkan biaya yang besar, dan sudah memulai untuk memakan makanan yang sehat dengan mengurangi makanan-makanan instan serta mengurangi penggunaan zat MSG ketika memasak.

\section{KESIMPULAN DAN SARAN}

\section{Kesimpulan}

Berdasarkan pembahasan diatas, penulis akan menyimpulkan bagaimana perencanaan komunikasi yang dilakukan pada program OMABA ini dan juga persepsi apa yang telah terbentuk pada orang tua yang anaknya pernah menjadi peserta OMABA setelah selesai mengikuti program.

UPT Puskesmas Riung Bandung telah melakukan tahap analisis dengan cara yang baik yaitu berkolaborasi dengan posyandu dan melakukan validasi secara terperinci dengan melakukan pemerikasaan kunjungan kerumahrumah sehingga akhirnya ditemukan bahwa karakteristik balita bergizi buruk dapat dilihat melalui grafik di KMS nya dan dapat dilihat dari bentuk fisiknya seperti sangat kurus, pantat yang melorot atau rambut kekuningan. Dalam analisis ini pun ditemukan penyebab utama dari terkenanya gizi buruk adalah karena pola asuh dan pola asup, dimana kedua hal tersebut terpengaruhi dari kondisi ekonomi masyarakat serta pengetahuan masyarakat yang terbatas. Untuk tahapan desain komunikasi, OMABA sudah menemukan khalayak sasarannya yaitu balita bergizi buruk, kemudian tujuan dari program ini adalah untuk guna memecahkan masalah gizi buruk dan mengembangkan sistem tata kelola gizi dan distribusi PMT. Namun, dalam penyampaian konten pesan, program OMABA ini masih belum menrancang media secara khusus, sejauh ini hanya menggunakan komunikasi interpersonal dengan cara spontanitas, tetapi walaupun tahapan ini belum sempurna, program ini masih berjalan secara efektif dan membuahkan hasil yang positif. OMABA pun sudah melakukan strategi perencanaan tindakan secara sistematis. Untuk tahapan 
pengembangan media, program OMABA masih membutuhkan banyak perbaikan, karena hingga saat ini UPT Puskesmas Riung Bandung masih belum mengonsep media yang digunakan secara matang, belum pernah melaksanakan uji coba terhadap program sebelum dilaksanakan, uji coba hanya dilaksanakan kepada makanan yang akan diantarkan. Pada tahap implementasi, monitoring, assessment untuk program OMABA sudah terlaksana dengan baik, karena para ibu-ibu OMABA pernah diberangkatkan pelatihan agar memiliki kapabilitas yang sesuai, program ini pun sudah berhasil diperkenalkan kepada khalayak sasaran yang dituju. Namun, UPT Puskesmas Riung Bandung masih harus melakukan penyempurnaan pada bagian monitoring, karena terkadang masih ada makanan yang tidak habis padahal makanan tersebut sudah diperhitungkan gizinya dan disesuaikan dengan kebutuhan anak. Tahapan terakhir dalam perencanaan komunikasi adalah telaah atau review. Sejauh ini, program OMABA dapat dinilai baik karena telah berhasil memiliki output yang baik, yakni membaiknya status gizi balita dan mampu membuat orang tua menjadi lebih peduli terhadap kesehatan anak dan memakan makanan yang bergizi. Sehingga program ini layak untuk dijadikan program yang berkelanjutan dengan adanya beberapa perbaikan untuk penyempurnaan.
Untuk persepsi yang terbentuk pada orang tua dengan anak bergizi buruk yang pernah menjadi peserta OMABA terdapat 3 faktor. Faktor pertama adalah faktor perhatian, disini lebih menekankan kepada stimulus yang diberikan seperti gerakan visual, sejauh ini OMABA tidak memiliki gerakan visual tertentu, namun OMABA berhasil melakukan pada aspek lainnya yakni melakukan tindakan atau hal mencolok sehingga diingat oleh peserta OMABA yaitu komunikator yang mampu menarik hati peserta OMABA agar dapat melakukan hal-hal yang memang diharapkan, seperti makan makanan sehat dan sebagainya. Lalu, OMABA ini dapat menarik perhatian peserta dengan menyajikan menu makanan yang unik dna variatif serta sistem delivery dalam program ini yang membuat peserta merasa tertarik, terlebih program ini dilaksanakan secara konsisten 90 hari sehingga dapat menarik perhatian peserta. Faktor yang kedua adalah faktor fungsional, yang dilihat dari latar belakang, pengalaman, dll. Orang tua peserta OMABA pada umumnya adalah keluarga dengan kondisi ekonomi rendah dna tingkat pendidikan yang rendah pula, karena Kelurahan Cisaranten Kidul terdapat banyak kantung-kantung kemiskinan, sehingga dipilihlah komunikator yang dapat menyampaikan apa yang dimaksud dengan menggunakan bahasa-bahasa ringan sehingga mudah dipahami oleh orang tua peserta OMABA. Faktor yang terakhir adalah faktor 
sturktural, pelaksanaan program OMABA ini telah menimbulkan efek positif bagi orang tua peserta OMABA. Setelah mengikuti OMABA orang tua peserta menjadi lebih peduli pada kesehatan dan mengubah perilakunya dalam menyajikan makanan.

\section{Saran}

Setelah melaksanakan penelitian dan analisis, terdapat saran yang dapat diberikan melalui penelitian ini yaitu;

(1) Penelitian ini merupakan penelitian kualitatif yang memiliki tujuan untuk mengetahui bagaimana perencanaan komunikasi pada program kesehatan dalam upaya membentuk persepsi orang tua dengan riwayat anak bergizi buruk. Disarankan untuk penelitian selanjutnya, tetap melaksanakan penelitian dengan subjek yang sama yaitu program OMABA, namun hal yang diteliti adalah kolaborasi yang berhasil dilakukan oleh UPT Puskesmas Riung Bandung sehingga dapat menjadi pelengkap penelitian ini agar dapat ditiru oleh puskesmas-puskesmas lainnya.

(2) Sebaiknya, untuk kedepannya UPT Puskesmas Riung Bandung menggunakan tenaga ahli yang memang fokusnya kepada bidang promosi kesehatan agar pengemasan pesan yang ingin disampaikan dapat tersusun secara sistematis.

(3) Ada baiknya, kedepannya UPT Puskesmas Riung Bandung melakukan kerjasama dan kolaborasi dengan pihak Dinas Sosial atau pihak lainnya yang sekiranya dapat memberikan pelatihan keterampilan kepada orang tua peserta OMABA, hal ini dilakukan agar setelah selesai mengikuti program ini, orang tua tidak jadi bergantung kepada OMABA namun tetap dapat memenuhi kebutuhan dan kecukupan gizi sang anak

(4) Ada baiknya, monitoring atau pengawasan dilakukan tidak hanya pada saat pelaksanaan program, tetapi juga setelah pelaksanaan OMABA untuk memastikan agar kondisi kesehatan dan kecukupan gizi anak tidak lagi menurun setelah selesai mengukuti program OMABA.

(5) Sebaiknya program Ojek Makanan Balita (OMABA) ini melakukan kerja sama dengan pihak Dinas Kesehatan, agar program mampu memperoleh atensi yang lebih dari pihak pemerintah sehingga dapat direplikasi oleh daerah lainnya.

\section{DAFTAR PUSTAKA}

Cangara, Hafied. 2013. Perencanaan \& Strategi Komunikasi. Depok: PT RajaGrafindo Persada

Cangara, Hafied. 2014. Perencanaan \& Strategi Komunikasi (Edisi Revisi). Depok: PT RajaGrafindo Persada

Effendy, Onong Uchjana. 2016. Ilmu Komunikasi: Teori dan Praktek. Bandung: PT Remaja Rosdakarya

Ikbar, Yanuar. 2012. Metode Penelitian Sosial Kualitatif: Panduan Membuat Tugas 
Akhir/Karya Ilmiah. Bandung: PT Refika Aditama

Moleong, Lexy J. 2014. Metodologi Penelitian Kualitatif. Bandung: PT Remaja Rosdakarya

Mulyana, Deddy. 2011. Ilmu Komunikasi Suatu Pengantar. Bandung: PT Remaja Rosdakarya

Notoatmodjo, Soekidjo. 2012. Promosi Kesehatan dan Perilaku Kesehatan. Jakarta: PT Rineka Cipta

Rakhmat, Jalaluddin. 2012. Psikologi Komunikasi. Bandung: PT Remaja Rosdakarya

Setiadi, Nugroho J. 2015. Perilaku Konsumen: Perspektif Kontemporer pada Motif, Tujuan, dan Keinginan Konsumen. Jakarta: Prenadamedia Group 